Article

\title{
Comparison of ecosystem services from mixed against monospecific forests in the Southwest Germany: A survey on public perception
}

\author{
Iulia Almeida ${ }^{1}$, Christine Rösch ${ }^{1}$, Somidh Saha ${ }^{1,2^{*}}$ \\ ${ }^{1}$ Institute for Technology Assessment and Systems Analysis, Karlsruhe Institute of Technology, \\ Germany \\ ${ }^{2}$ Chair of Silviculture, Institute of Forest Sciences, Albert Ludwigs University of Freiburg, Germany \\ *Corresponding author address and contact information: Karlstr. 11, Institute for Technology \\ Assessment and Systems Analysis, Karlsruhe Institute of Technology, D-76133 Karlsruhe, Germany; \\ Email: somidh.saha@kit.edu; somidhs@gmail.com
}

Abstract: Scientific studies had shown that mixed forests of silver fir (Abies alba Mill.) and European beech (Fagus sylvatica L.) provide higher ecosystem services than monospecific forests. Mixed forests are known for their high resilience to climate change impacts and superior biodiversity compared to monospecific forests. In many countries, promotion of mixed forests in forest management is becoming a government policy since they can contribute to fulfill the Sustainable Development Goals set by the United Nation, respectively Goal 13 and 15. However, not much is known about public perceptions on mixed forests compared to monoculture forests. Our study on ecosystem services provided by mixed and monospecific forests in southwest Germany fill this gap. Based on a survey with 520 valid responses we analyzed people's perception on 18 different supporting, cultural, regulating and provisioning ecosystem services measured by Likert scale. Stepwise regression analyses show relations between social profiles (gender, age, education, profession) and preferences on respondents' perceptions. Our findings show that people perceive that mixed forests provide better cultural, regulating and supporting ecosystem services than monospecific forests of fir and beech whereas provisioning services were perceived as being equally or better provided by monospecific forests. Significant effects towards a positive perception on ecosystem services provided by mixed forests were mainly influenced by the perceived abundance of old trees, feeling of pleasantness in mixed forests, age, profession, and education. Our findings indicate that there is a high public support for the promotion of silver fir and beech mixed forests in Southwest Germany.

Keywords: Mixed forests; Questionnaire Survey; Ecosystem Services; Stepwise Regression; Climate Change

\section{Introduction}

The demands on forest ecosystem services have increased due to rapid human population growth and depletion of natural resources, consequently, threatening the continuous supply of ecosystem services. In addition, climate change impacts are limiting or even reducing the capability of 
forest ecosystems to meet human needs [1] and are challenging forest management globally. Along with the rise of the global average surface temperature, there is a high risk of increase in extreme events, such as heat waves, floods and droughts [2,3]. Forests are believed to be especially prone to climate change impacts due to long life span of trees, in addition to the low migration rates of various species inhabiting forest ecosystems [4,5]. An alteration in climatic conditions will affect species distribution, local species composition and consequently forest structure. These changes will influence forest biodiversity and ecosystem functions, thus representing a challenge to the provision of ecosystem services, on which human well-being depend on [6,7]. Hence, there is strong need to develop possible adaptation strategies for forest ecosystems to increase the resilience of forests against climate change, while enhancing forest functions and the provision of ecosystem services [4]. As a result, incorporating adaptation and mitigation strategies in forest management have become a policy goal for the countries around the world. For example, in 2015, the United Nation set up Sustainable Development Goals (SDGs) for the "2030 Agenda for Sustainable Development” to promote sustainable forest management and increase resilience [8]. In particular Goal 13 “Climate Action" and Goal 15 "Life on Land" aim to combat the negative impacts caused by climate change and to protect and promote the sustainable use of forests and other terrestrial ecosystems, as well as to stop biodiversity loss and land degradation [8].

Since the beginning of European forest science in the $18^{\text {th }}$ century scholars have debated whether mixed forests can deliver better or preferred ecosystem services than monospecific forests [9].

Nadrowski, et al. [10] reviewed studies on this topic and found that generally tree species diversity is positively related to forest productivity. Gamfeldt, et al. [7] showed that species-rich forests have positive relationships with various ecosystem services, including biomass production, carbon storage, supply of berries and game stock. Furthermore, diversity at a landscape level is expected to buffer insect outbreaks, fire, storms and other disturbances related to climate change [4].

In Germany, adaptation strategies for forest management towards climate change are already being implemented even though they remain in an early stage and the approaches vary between locations [4,11]. German forestry is shifting from a timber-production enterprise towards a more comprehensive multifunctional sustainable forest management with an emphasis on social and ecological objectives. Furthermore, there is an increasing focus in achieving self-sustained forest functions and processes, as well as enhancing the provision of ecosystem services [6,9,12].

In the European Union, the protection of ecosystem services is promoted through the EU 2020 Biodiversity Strategy, which recognizes ecosystem services and biodiversity as being fundamental for human life, wealth, economics and well being [13]. This strategy also recognizes cultural services as having utmost importance. Cultural services are defined as "ecosystem contributions to the nonmaterial benefits (e.g. capabilities and experiences) that arise from human- ecosystem relationships" [14]. Studies have shown that societies become less dependant on provisioning (e.g. firewood) with higher economic development, while they become more dependant on cultural services $[15,16]$. Besides their importance, cultural services have been rarely assessed in scientific literature; apart from tourism and recreation $[14,16]$. Furthermore, as they represent complex relationships between ecosystems and humans, it is very difficult to quantify their importance [16]. Current publications of 
cultural ecosystem services have mainly focused on economic, as well as biophysical assessments. However, the socio-cultural aspects has not been thoroughly evaluated [17].

Against this background our study aims to contribute in gaining more insights on preferences, beliefs and perceptions of people about ecosystem services from different forest management practices (e.g. mixed vs. monospecific) in order to understand how these services contribute to human well-being. Such studies are still rare in central Europe [9].

Since mixed forests had shown higher stability and resistance against extreme events such as storm and drought, mixing tree species is assumed as adaptive measure to increase resilience of forests $[4,12]$. Besides, higher diversity in mixed forest stands has demonstrated to promote the provision of regulating ecosystem services, such as protection against fire or pathogen damages. Although beech is a natural species of Southwest Germany, they are becoming susceptible to drought induced die-back as climate warms [18]. Recent studies found that co-occurring tree species could reduce drought effect on beech trees by facilitative interactions $[19,20]$. The reason for this is that flat and shallow rooting silver fir and deep rooting beech trees could increase the water use efficiency in trees by hydraulic redistribution of water, hence, reducing drought stress in beech trees [21]. The growing scientific evidence on the benefits of mixed forests motivated foresters and landowners to promote mixed forests in Germany, however, studying public perception on this matter received little attention so far.

To this day, in Germany, there had not yet been any specific studies about perceptions of people on ecosystem services, while comparing mixed and monospecific forest in the context of adaption to climate change. The presented research study aims to fill this gap by assessing the perceptions of people on ecosystem services provided by mixed and monospecific forests of fir and beech in Southwest Germany by the means of an online questionnaire survey. The study is guided by following research questions:

1. What are respondents' preferences when comparing mixed and monospecific forests of fir and beech?

2. What are respondents' perceptions on ecosystem services provided by mixed forests compared to monospecific forests of fir and beech?

3. How are respondents' perceptions being influenced by social profiles, such as age and profession, as well as their habits and preferences?

\section{Materials and Methods}

\subsection{The Study Region Southwest Germany}

The focus of the current study is on the hilly region of the Black Forest and the state of BadenWürttemberg (where the Black forest belongs to), located in Southwest Germany, as this region has the natural potential for mixed forests of silver fir and European beech. In the study region mixed forests experienced in the past a strong deforestation and forest conversion that dates back around 2,000 years ago. In the $19^{\text {th }}$ century, Norway spruce (Picea abies (L.) H. Karst.) was planted to restore the forests in Southwest Germany. From then on monospecific coniferous stands dominated the forest landscape [22]. Since the catastrophic winter storms (i.e. extratropical cyclones) of 1990s, foresters try 
to convert these coniferous monocultures into mixed stands through re-introducing broadleaf tree species [18]. Forest districts in the Black Forest region started in 2004 to convert even-aged monocultures of conifers into a mixed, structurally rich, uneven-aged forest [23-25]. The European beech is playing an important role in this forest development strategy, as it belongs to the potential natural vegetation of Southwest Germany $[18,26]$. The success of this mixing forest becomes apparent by the increase of beech dominated forest cover from under 18\% to 22\% between 1987 and 2012 respectively. The objective for beech dominated mixed forest in public owned woodlands of BadenWürttemberg is to further raise their share up to $30 \%$ by 2100 [27-29].

According to the third German National Forest Inventory in 2012, the forests in our study region are part of the forests in the state of Baden-Württemberg which compromises $53 \%$ and $47 \%$ coniferous and deciduous forests, respectively [29]. Norway spruce accounts for the largest share among the dominant tree species (34\%), followed by beech (22\%), silver fir (8\%) and oak (7\%). Maple and ash (together $8 \%$ ) are also important species in ad-mixtures. The aim of the forest management is to create silver fir and beech forests mixture in appropriate sites in long term to cope with the negative impacts from droughts and storms [30]. The distribution of silver fir and European beech trees overlaps in Southwest Germany and can naturally co-occur at sites above $500 \mathrm{~m}$ of elevation (Fig. 1).

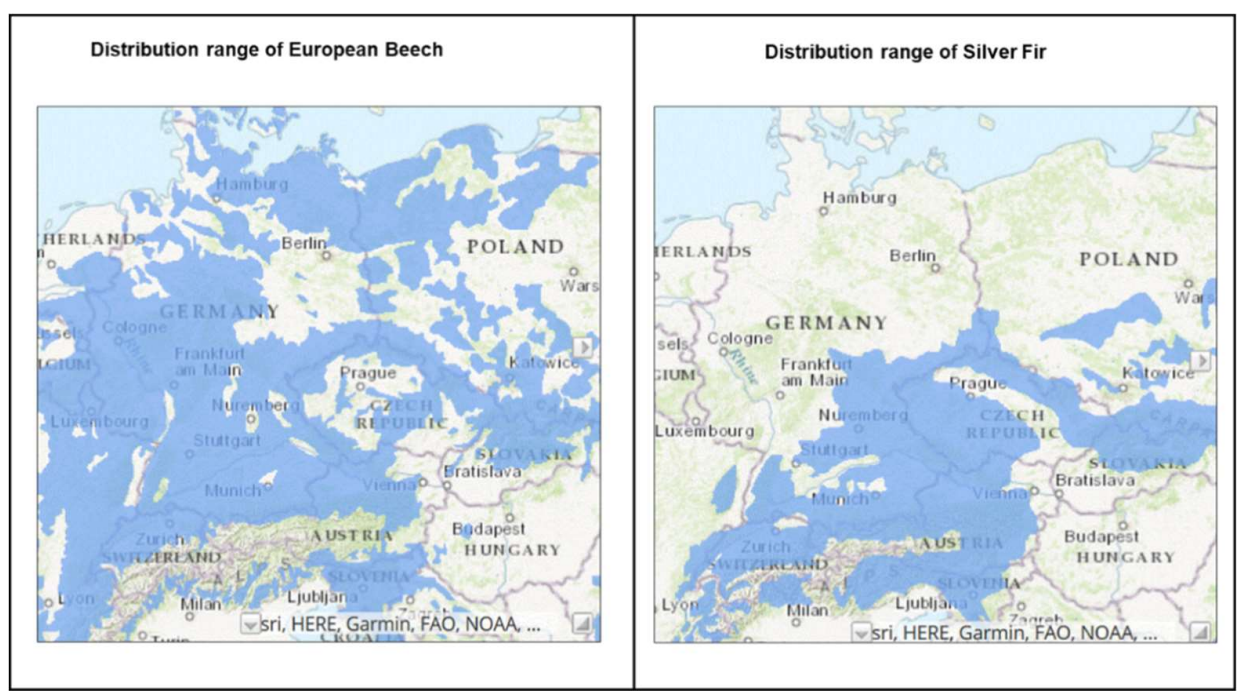

Figure 1. Distribution range of European beech and of Silver Fir [31]. Note that in the Southwest Germany, natural distribution of these two species overlaps.

\subsection{Design of the questionnaire}

A web-based questionnaire was designed using the platform www.umfrageonline.de [32] to perform the online survey. Invitations to participate in the questionnaire were sent via e-mail to key persons in Baden-Württemberg associated to different organizations and institutions, such as forestry organizations, environmental associations, NGOs, timber/forest industries, universities, forest and environmental research institutions, tourism and recreation associations, political parties, and local councils. The key persons were asked to forward the questionnaires to other possible participants using the "snowballing" process, where selected persons put the researcher in touch with other potential contributors $[9,33]$. In addition, the link to the survey was shared and distributed in social 
media, in particular on Twitter and Facebook. The people who participated in our survey are hereinafter referred to as "respondents'.

The respondents were categorized into six key stakeholder groups:

[1] foresters and people working in forest industries;

[2] policy makers;

[3] researchers;

[4] people working in NGOs;

[5] people associated to tourism and recreation clubs (hiking, biking, horse riding, hunting etc.);

[6] students; and

[7] others (e.g. teachers, engineers etc.)

The web-based questionnaire was based on three main sections:

[1] respondents' preferences between mixed and monospecific forests of silver fir and beech

[2] respondents' perception on ecosystem services provided by mixed versus monospecific forests of silver fir and beech and

[3] respondents' social profile.

It is an accepted fact that people's perceptions are formed differently according to beliefs, experiences, cultural expectations, motivations and attitudes [9]. To elicit how these factors have an influence on respondents' expectations on forest ecosystem services, information about the social profile of the respondents such as profession, age, gender, and preferred recreational activities were gathered for each respondent.

The understanding of ecosystem services and the structure to cluster the different ecosystem services to make them manageable for the questionnaire is based on the work of the Millennium Ecosystem Assessment (MEA). According to MEA ecosystem services are "benefits that people obtain from ecosystems and which contribute to human well-being" [1] and can be classified into four main categories:

[1] supporting ecosystem services (nutrient cycling, biodiversity, resistance against pathogens and illnesses, etc.);

[2] regulating ecosystem services (carbon sequestration, filtration of pollutants, soil stability against erosion, etc.);

[3] provisioning ecosystem services (provision of food, fuel, wood, game stock, financial return, etc.); and,

[4] cultural ecosystem services (recreation, tourism, aesthetic experience, etc.) [1].

\subsubsection{Respondents' social profile}


The first part of the survey comprised questions about respondents' gender, age, education level, profession, and whether that profession was related to forests and forest ownership. Besides, data about respondents' habits, such as frequency of visit to the forest, and preferred recreational activities were raised. The respondents were clustered into 4 age classes: (1) 18 to 25, (2) 26 to 40, (3) 41 to 60 and (4) over 60 years old. Respondents were asked to rank their three most preferred forest activities out of 13 recreational activities offered. After the completion of survey, those activities were grouped into 9 main activities for further data analysis (Table 1).

Table 1. Simplification of recreational activities addressed in the survey for data analysis

\begin{tabular}{ll}
\hline Detailed activities (questionnaire) & Simplified activities (data analysis) \\
\hline Hiking, walking, jogging & Hiking \\
Biking and mountain biking & Biking \\
Horse riding & Horse riding \\
Hunting & Hunting \\
Collecting mushrooms, wild garlic and other plants; & Collecting plants and mushrooms \\
wild honey and fruits (NWFP) & (NWFP) \\
Collecting firewood & Collecting firewood \\
Picnicking & Picnicking \\
Observing plants and animals & Observing plants and animals \\
Meditating, having a spiritual experience & Meditating \\
\hline
\end{tabular}

\subsubsection{Respondents' preferences between mixed and monospecific forests of fir and beech}

The second part of the survey comprised questions about respondents' preferences between mixed and monospecific forests of fir and beech. One crucial objective here was to investigate of the perceived pleasantness of silver fir-beech mixed forests in comparison to monoculture of the respective species. The participants were asked if they believe that old trees can be found rather in mixed forests than in monospecific forests of silver fir and beech. This question is based on the assumption that people like the appearance of old and big trees and that they might have the impression that these trees are more frequent in mixed forests than monospecific forests. We also asked respondents whether people have a stronger "sense of home" in monospecific forests of silver fir or beech over mixed forests.

2.2.3 Respondents' perception on ecosystem services provided by mixed forests compared to monospecific forests of fir and beech

In the third part of the survey respondents were asked to give their opinion on 18 different ecosystem services (Table 2) based on MEA [1] and Carnol et al. [9]. In doing so they had to rank their answers within a 5-point Likert's scale [34] with the following interpretation: (1) fully agree, (2) rather agree, (3) neither agree nor disagree, (4) rather disagree, and (5) fully disagree. In addition, the 
respondents had the option "I don't know" (DK). The DK option allows the respondents to express their unawareness for any specific question [35].

Table 2. List of ecosystem services in the survey to be ranked by respondents

\begin{tabular}{|c|c|c|}
\hline $\begin{array}{l}\text { Ecosystem } \\
\text { services }\end{array}$ & Key word & $\begin{array}{l}\text { Compared to monospecific forests mixed forest } \\
\text { have... }\end{array}$ \\
\hline Provisioning & $\begin{array}{l}\text { Timber yield } \\
\text { Biomass } \\
\text { Profitability } \\
\text { Hunting } \\
\text { Non-wood forest } \\
\text { products }\end{array}$ & $\begin{array}{l}\text { higher timber yield } \\
\text { higher biomass productivity } \\
\text { higher monetary/economical profitability } \\
\text { higher availability of wild game populations } \\
\text { better opportunities to collect mushrooms, fruits, wild } \\
\text { garlic, honey, etc. }\end{array}$ \\
\hline Cultural & $\begin{array}{l}\text { Recreation } \\
\text { Tourism } \\
\text { Education } \\
\text { Observing plants } \\
\text { and wildlife }\end{array}$ & $\begin{array}{l}\text { better and manifold recreation possibilities and allow } \\
\text { spiritual experience } \\
\text { higher attractiveness for tourism } \\
\text { higher contribution to education } \\
\text { provide better opportunities for observation of plants } \\
\text { and animals }\end{array}$ \\
\hline Regulating & $\begin{array}{l}\text { Pollution Control } \\
\text { Water retention } \\
\text { Erosion } \\
\text { Carbon storage }\end{array}$ & $\begin{array}{l}\text { higher capacities to control pollution and keep the air } \\
\text { clean and thus to improve human health } \\
\text { higher potential to increase water retention capacity } \\
\text { (ability of the soil, to retain water) } \\
\text { better function for soil protection against erosion } \\
\text { higher ability for carbon storage }\end{array}$ \\
\hline Supporting & $\begin{array}{l}\text { Resilience to } \\
\text { climate change } \\
\text { Biodiversity } \\
\text { Resistance to } \\
\text { storms } \\
\text { Resistance to } \\
\text { droughts } \\
\text { Resistance to } \\
\text { diseases }\end{array}$ & $\begin{array}{l}\text { higher capacity to return to its original state after } \\
\text { disturbances caused by climate change } \\
\text { higher diversity of habitats, plants \& animals species } \\
\text { higher resistance against storm events }\end{array}$ \\
\hline
\end{tabular}

Supporting services are so-called enabling services as they provide the requirements for the generation of other ecosystem services, including biomass production, soil formation and retention, as well as the provisioning of habitats. Thus, well-being of humans is a result of supporting services provided by provisioning, regulating and cultural ecosystem services [15]. Resilience is usually not considered as an ecosystem service, although we compromised it in the category of supporting ecosystem services, together with resistance to drought, storm and diseases. However, the assessment of respondents' perceptions on resilience of forest ecosystems was crucial for our findings, as maintaining forest resilience is an important climate change adaptation and mitigation mechanism [36]. 
2.3 Data analysis

The survey resulted in 520 valid responses which were included in the analysis. Duplications of responses were prevented by allowing that the questionnaire link could only be used once in an electronic device. The survey portal used automatically saved the responses and created a database in Microsoft Excel for statistical analyses.

The data analysis was done in two steps. First, a set of descripted analyses were carried out on respondents' preferred activities in forests and perceptions on ecosystem services addressing the respondents' preferences when comparing mixed and monospecific forests of fir and beech and their perceptions on ecosystem services provided by monospecific and mixed forests.

Second, variance and regression analysis were carried out to investigate the relations between social profiles and people's preference for ecosystem services between silver fir-beech mixed forests and monospecific forests of respective species. Therefore, we averaged the Likert's values to four major categories of supporting, regulation, cultural and provisioning services. The average value of Likert's scores was used as a dependent variable in each category. We had 10 categorical and binary explanatory variables:

[1] stakeholder groups

[2] level of education

[3] resident of the Black Forest region

[4] gender

[5] age

[6] frequency of forest visit

[7] forest ownership

[8] pleasantness,

[9] sense of home

[10] frequency of big and old trees.

The regression analysis was carried out with the "Automatic Linear Modelling" (ALM) version 20 of the recent IBM-SPSS program described by Yang [37] and in the web guidelines for SPSS.20 [38]. With that we could use a feature to select the categorical binary variables after performing collinearity analysis through a stepwise regression approach. The regressions excluded the auto correlated variables. Akaike's Information Criterion was used for the selection of final outputs. The parameter estimates were used to measure the significance of the relationship between target and explanatory variables. The ALM package also calculated a parameter called "predictor's importance" which range from 0 to 1 and higher values indicating higher significance. The importance of the predictor or explanatory variable is the residual sum of squares with the predictor removed from the model, normalized so that the importance values sum to 1 . It allowed us to rank the explanatory variables based on their statistical importance. The parameter estimates of each explanatory variable of a 
regression output generated was used to plot for better visualization by the package "plotrix" of $R$ Statistical Program [39,40]. The confidence interval of parameter estimate should not touch 0 for a significant effect. The negative value of the parameter estimate denotes a negative effect, whereas, the positive value of the parameter estimate would mean a positive effect.

\section{Results}

3.1 Respondents' social profile

Out of 520 respondents, 38\% were female and 62\% male. Most of the respondents were 18 to 40 years old, representing $64 \%$ of the total sample (Figure 2, top left). About $62 \%$ of the responds attained a university degree (Figure 2, top right). Researchers (27\%) represented the largest stakeholder group, followed by forestry professionals (25\%) and students (18\%). Respondents working in policy and decision making (Figure 2, bottom left), NGOs, tourism and recreation organizations were nearly equally represented. Almost $13 \%$ of the respondents belonged to the group of private forest owners. Around $60 \%$ of the respondents lived in the Black Forest area. Majority of the respondents $(80 \%)$ visited the forest all year round and did not have a specific seasonal preference (Figure 2, bottom right). Frequency of forest visits was nearly equal (i.e. 28\%) between people who visited forests weekly and monthly. Close to $38 \%$ of respondents visited forests daily or multiple days in every week, whereas only $6 \%$ visited forests less often.

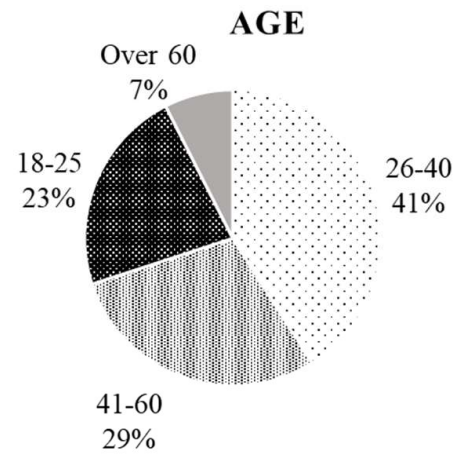

STAKEHOLDER GROUPS

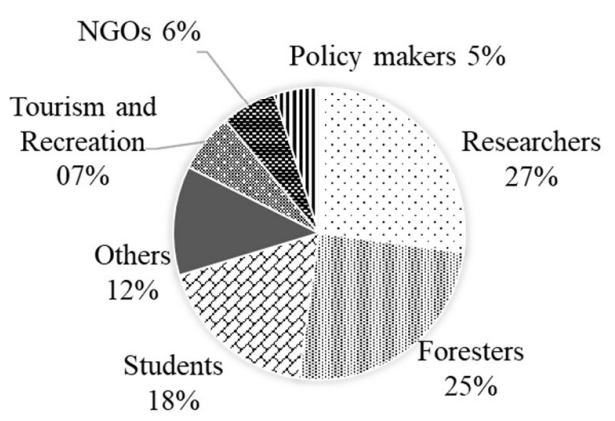

\section{EDUCATION LEVEL}

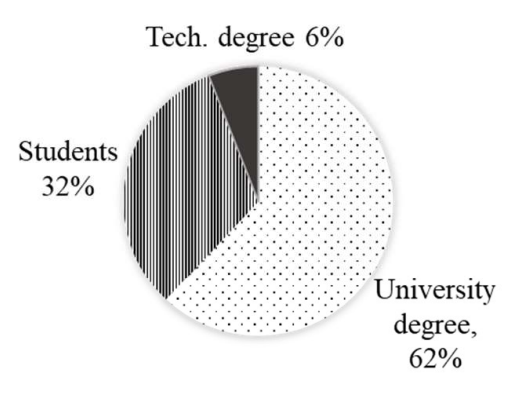

FREQUENCY OF FOREST VISIT

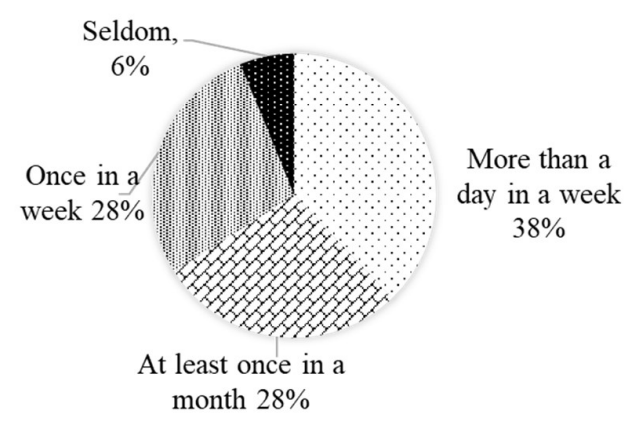

Fig. 2 Respondents' social profile and their frequency of forest visit. 
3.2 Respondents' preferences on recreational activities

Each respondent could choose up to three preferred recreational activities. The percentage values were calculated from the 1,134 preferences from 520 respondents. The recreational activity preferred by nearly all respondents (96\%) was hiking suggesting that a large percentage of people go to the forest for recreation (Figure 3). Observing plants and wildlife, and collecting mushrooms, gathering firewood, picnicking, bicycling and hunting were other popular recreational activities. However, activities such as meditation and horse riding were only preferred by a small percentage $(<20 \%)$ of the respondents.

PREFERRED RECREATIONAL ACTIVITIES

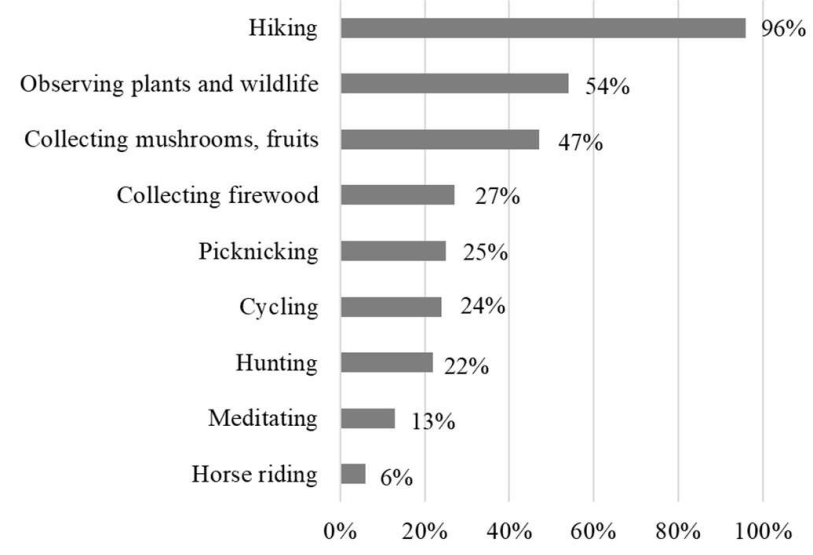

Fig. 3 Preferred recreational activities of the respondents. Each respondent could choose up to three preferred recreational activities. The percentage values were calculated from the 1,134 preferences from 520 respondents.

Nearly $80 \%$ of respondents perceived that pleasantness of mixed silver fir-beech forests was greater than monospecific forests (Fig. 4). 46\% of the respondents believed that old and big trees are more likely to be found in silver fir-beech mixed forests rather than monospecific forests. 59\% respondents had higher sense of home in silver fir-beech mixed forests whereas $24 \%$ and $17 \%$ of the respondents feel more at home in beech and fir monospecific forests, respectively.
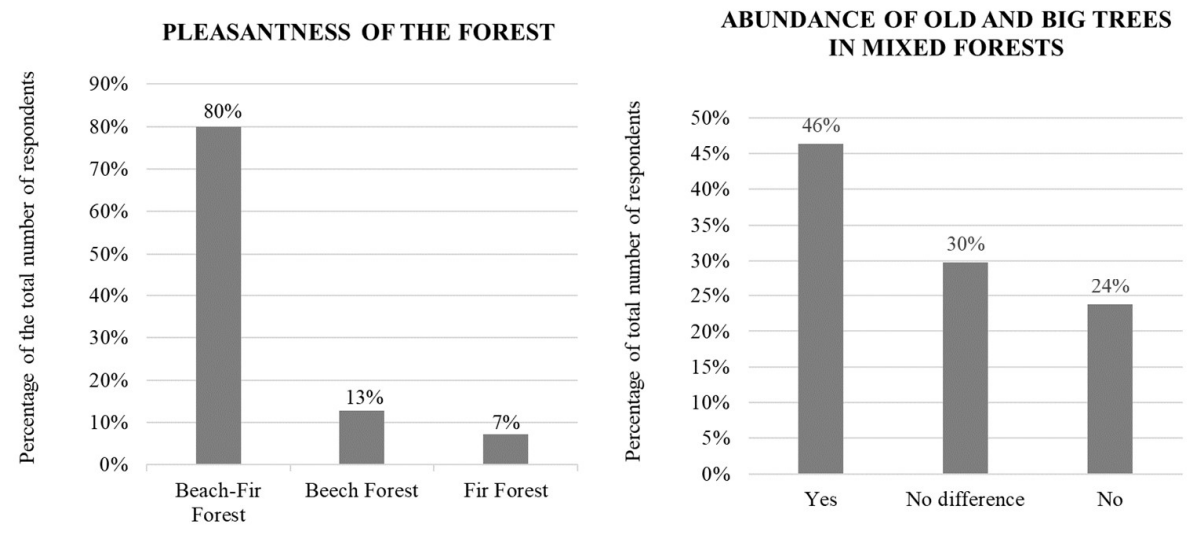

Fig.4 Respondents' $(\mathrm{N}=520)$ feeling on the pleasantness of the forest and abundance of old and big trees in mixed forests compared to monospecific forests. 
3.3 Respondents' perceptions on ecosystem services

Overall, respondents perceived that mixed forests provide higher ecosystem services than monospecific forests of fir and beech. The question on ecosystem services such as biodiversity, resilience against climate change, and resistance to diseases were the ones that obtained the smallest mean, thus the most positive answers in a range between 1.4 and 1.5 (Fig. 5). Conversely, ecosystem services such as profitability, timber yield, and hunting potential were the items that obtained the most negative responses, having means of 3.0, 2.8 and 2.6 respectively.

\section{RESPONDENTS' PERCEPTIONS ON 18 \\ ECOSYSTEM SERVICES \\ (not counting D.K. answers)}

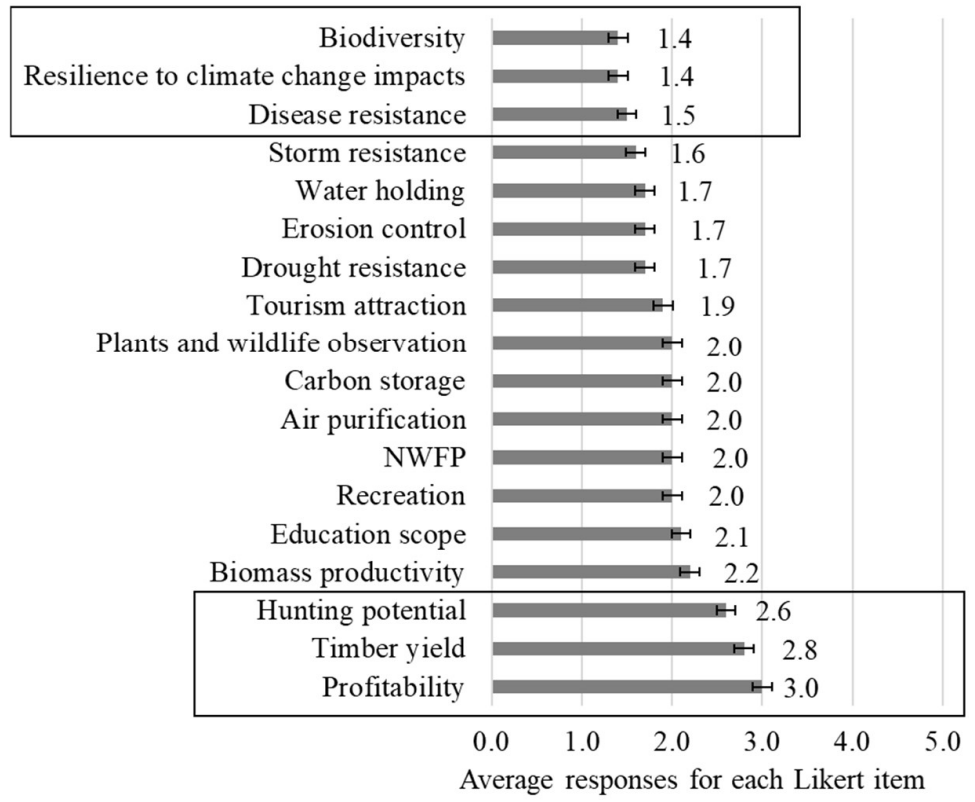

Fig. 5 Average perceptions on different ecosystem services provided by mixed forests compared to monospecific forests. The perceptions were measured for 18 ecosystem services (i.e. Likert's items) in a 5-point scale ( $1=$ strongly agree, $5=$ strongly disagree), without counting D.K. (I don't know) answers.

The "I don't know" (D.K.) responses varied between ecosystem services. Among them biodiversity, plant and wildlife observation, and recreation were the ones with the least D.K. responses (Fig. 6). In contrast, hunting potential, profitability and timber yield obtained the most D.K responses. This suggests that the respondents' awareness on these three latter ecosystem services might not be adequate. 


\section{D.K. ANSWERS ONLY}

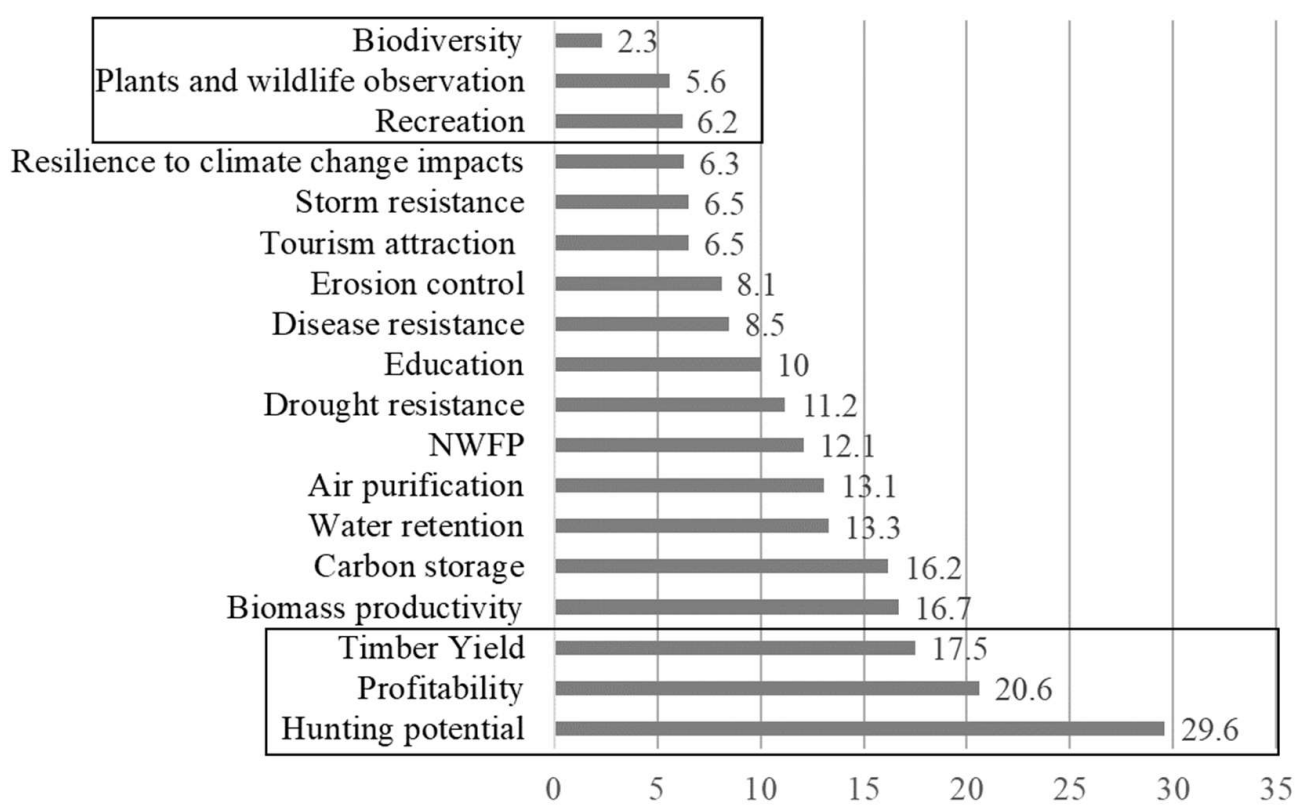

Percentages of respondents who gave a D.K answer for Likert variable

Fig. 6 Percentages of respondents provided "I don't know" (D.K.) response for each ecosystem service or Likert item. Note that the percentage was calculated from the total number of respondents for each Likert item related to the other response categories ( $1=$ fully agree to $5=$ fully disagree). For instance, only $2.3 \%$ of the respondents provided a D.K response regarding biodiversity related to the other response categories.

We averaged the Likert's score of 18 ecosystem services into four classes of supporting, regulating, cultural, and provisioning services and plotted them against 10 social profiles and preferences (Table 3, Fig. 7). We found a general trend of higher positive perceptions (i.e. lower Likert's values) in supporting services; followed by regulating, cultural and provisioning services. This trend was consistent among all 10 variables although had some variations. The analyses of variances (ANOVAs) showed that all four types of ecosystem services varied significantly within the different classes of social variables such as education level, age, and as well as by preferences on pleasantness, sense of home and frequency of old and big trees in forests (Table 3, Fig. 7). The responses varied significantly between male and female respondents for the provisioning, cultural and regulating services but not for the supporting services. The responses for provisioning and cultural services varied between different stakeholder groups. The perceptions on cultural ecosystem services varied by residency, frequency of forest visit and forest ownership (Table 3, Fig. 7). 
Table 3 Analyses of variances (ANOVAs) of average Likert's score for different types of ecosystem services within 10 variables related to social profiles and preferences of respondents. Numbers in bold are significant responses.

\begin{tabular}{|c|c|c|c|}
\hline $\begin{array}{l}\text { Social profiles and preferences of } \\
\text { respondents }\end{array}$ & Type of ecosystem services & F-value & p-value \\
\hline \multirow{4}{*}{ Stakeholder groups } & Provisioning & 2.45 & 0.0242 \\
\hline & Cultural & 7.06 & 0.0000 \\
\hline & Regulating & 1.62 & 0.1396 \\
\hline & Supporting & 1.02 & 0.4095 \\
\hline \multirow{4}{*}{ Level of education } & Provisioning & 5.21 & 0.0057 \\
\hline & Cultural & 9.20 & 0.0001 \\
\hline & Regulating & 6.76 & 0.0013 \\
\hline & Supporting & 3.83 & 0.0224 \\
\hline \multirow{4}{*}{ Residence } & Provisioning & 0.15 & 0.6960 \\
\hline & Cultural & 4.91 & 0.0272 \\
\hline & Regulating & 1.32 & 0.2518 \\
\hline & Supporting & 0.53 & 0.4657 \\
\hline \multirow{4}{*}{ Gender } & Provisioning & 12.25 & 0.0005 \\
\hline & Cultural & 25.35 & 0.0000 \\
\hline & Regulating & 7.64 & 0.0059 \\
\hline & Supporting & 1.94 & 0.1647 \\
\hline \multirow{4}{*}{ Age } & Provisioning & 5.12 & 0.0017 \\
\hline & Cultural & 4.41 & 0.0045 \\
\hline & Regulating & 3.71 & 0.0116 \\
\hline & Supporting & 3.10 & 0.0263 \\
\hline \multirow{4}{*}{ Frequency of forest visit } & Provisioning & 0.61 & 0.6105 \\
\hline & Cultural & 3.47 & 0.0161 \\
\hline & Regulating & 1.22 & 0.3002 \\
\hline & Supporting & 0.89 & 0.4464 \\
\hline \multirow{4}{*}{ Forest ownership } & Provisioning & 0.70 & 0.4039 \\
\hline & Cultural & 9.06 & 0.0027 \\
\hline & Regulating & 2.01 & 0.1566 \\
\hline & Supporting & 7.52 & 0.0063 \\
\hline \multirow{4}{*}{ Pleasantness of forest } & Provisioning & 4.46 & 0.0121 \\
\hline & Cultural & 17.96 & 0.0000 \\
\hline & Regulating & 13.08 & 0.0000 \\
\hline & Supporting & 6.40 & 0.0018 \\
\hline \multirow{4}{*}{ Sense of home } & Provisioning & 8.85 & 0.0002 \\
\hline & Cultural & 22.94 & 0.0000 \\
\hline & Regulating & 9.99 & 0.0001 \\
\hline & Supporting & 4.30 & 0.0141 \\
\hline \multirow{4}{*}{ Frequency of old and big trees } & Provisioning & 13.79 & 0.0000 \\
\hline & Cultural & 40.14 & 0.0000 \\
\hline & Regulating & 35.10 & 0.0000 \\
\hline & Supporting & 23.86 & 0.0000 \\
\hline
\end{tabular}




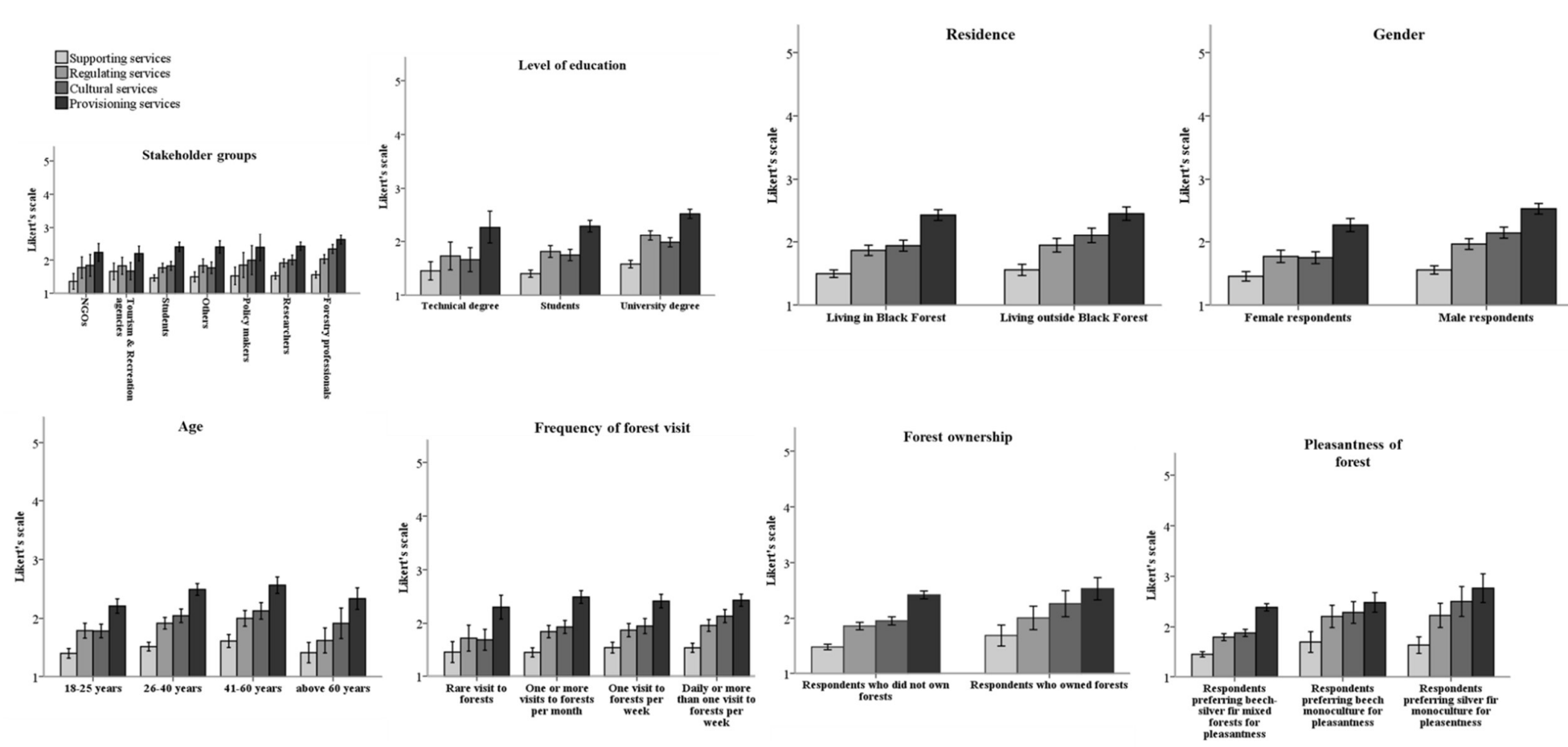

2 Fig. 7 Variations of respondents' perceptions (i.e. average Likert's scores) on supporting, regulating, cultural and provisional ecosystem services within 10 variables related 3 to social profiles and preferences. The thin bars indicate the standard error of the average Likert's score at $95 \%$ level of confidence. 


\section{forests}

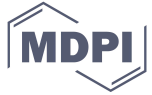

3.4 Influences of social profile and preferences of the respondents on their perceptions on ecosystem services

In the previous section, we showed how people's perceptions on ecosystem services varied within 10 variables related to their social profiles, habits, and preferences. We found 4 to 6 most important variables for each category of ecosystem services (Fig. 8). Respondents' perception on the occurrence of big and old trees, pleasantness of forests, age and education were the four most important variables (Fig. 8). Respondents' feeling of higher number of old and big trees in mixed forest was significantly related to lower Likert's values (i.e. better services in mixed forests than monospecific forests) in all four types of ecosystem services (Fig. 9). Their perception on greater pleasantness of silver fir-beech mixed forests was also an important variable, and people with that perception were more likely to believe of higher supporting, regulation and cultural services in mixed forests than monospecific forests. Level of education was important because the beliefs of higher cultural, supporting and regulating services in mixed forests over monospecific forests were significant among students and people with technical degrees. The age of respondents was found to be an important variable for supporting, regulating and provisioning services. The young respondents of age $18-25$ years believe that mixed forests provide higher supporting ecosystem services, however, this trend was opposite for regulating and provisioning services. People who had strong sense of home in mixed forests were more likely to believe that those forests provide higher cultural and provisioning services than monospecific forests. The gender was an important factor behind the perception of the cultural ecosystem service but not in other services. Male respondents were more likely to believe that cultural ecosystem services were lower in mixed forests than monospecific forests than female respondents.

Besides these expected and explainable results of the survey we got two outcomes that didn't fulfil our expectations. First, the stakeholder groups (people were listed as per their profession) was found to be important only for the cultural ecosystem services but not for the other services. People who were employed in forestry sector were less likely to think that mixed forests provide higher cultural services than monospecific forests. Other professions were significant for the cultural services. Second, respondents who didn't own any private forest lands were more likely to believe about higher supporting ecosystem services in mixed forests than the private forest owners (Fig. 9). 

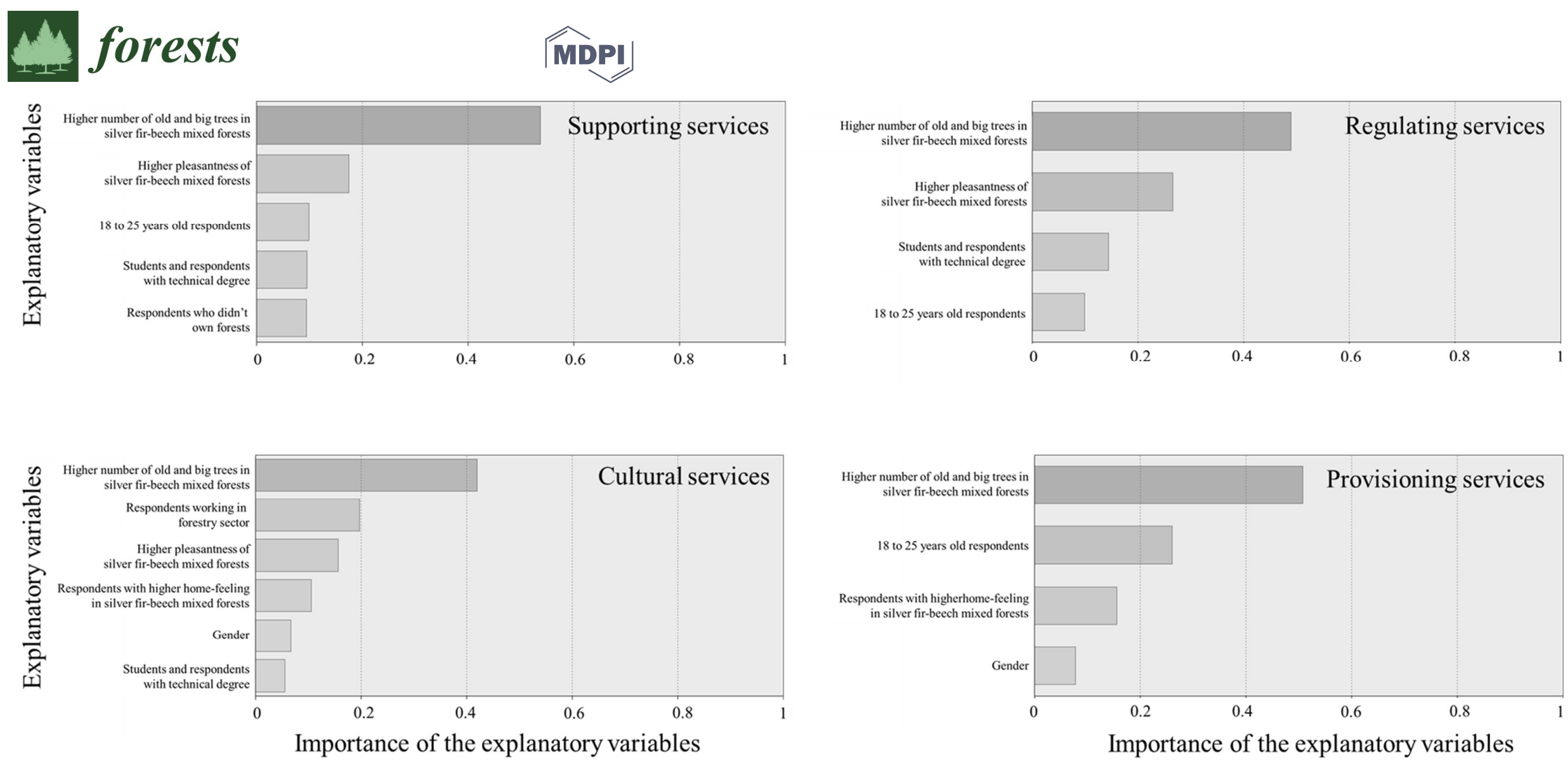

Fig. 8 The list of most important explanatory variables included in final regression analyses based on their importance values generated during automatic stepwise regressions. Higher score denotes greater importance of a respective variable. 


\section{forests}
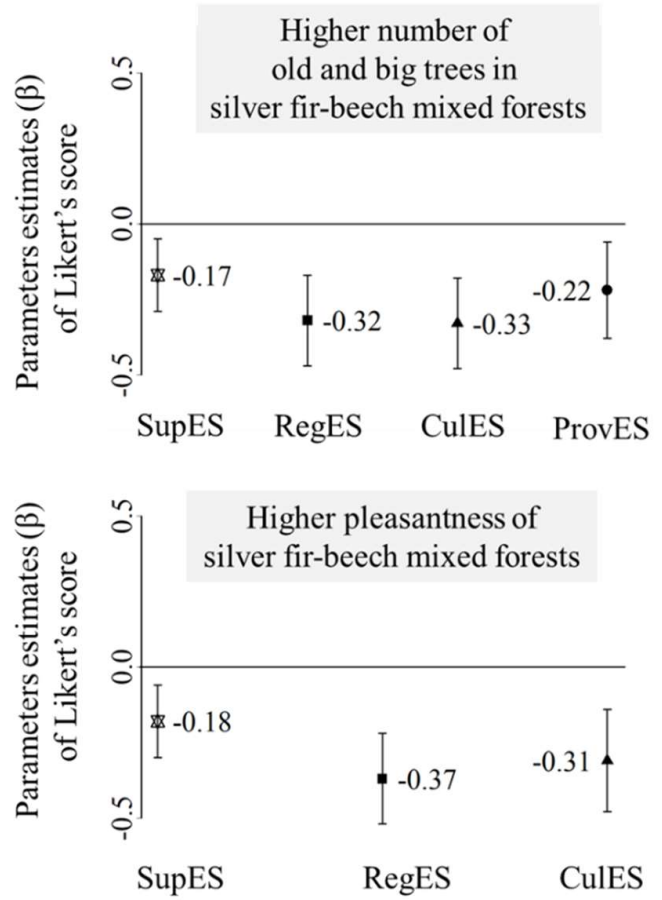
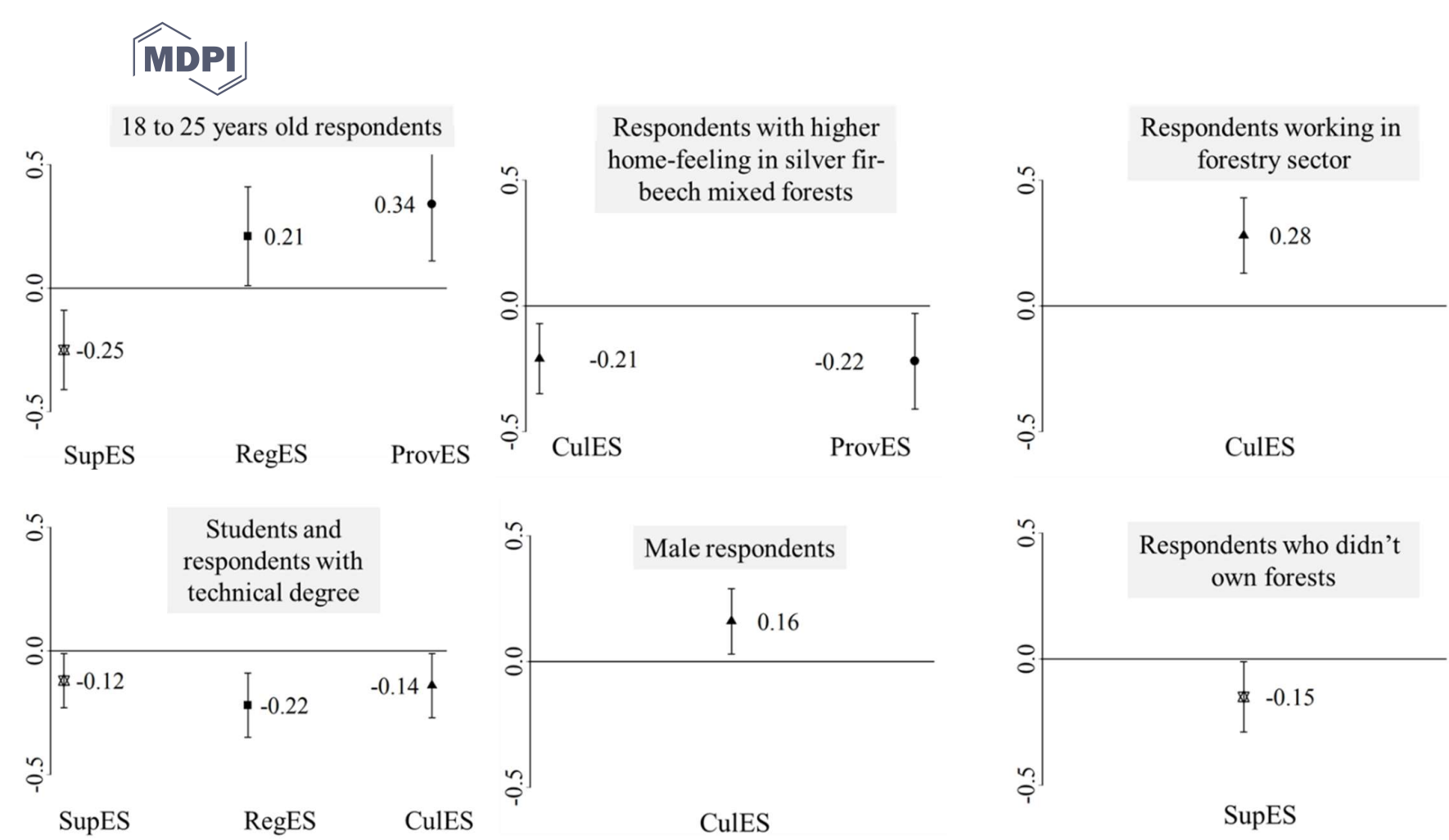

Fig. 9 Results of four stepwise regression analyses for supporting (SupES), regulating (RegES), cultural (CulES), and provisioning (ProvES) services. 


\section{forests}

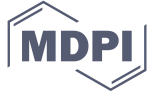

\section{Discussion}

In the present study, respondents' perceptions on ecosystem services provided by mixed and monospecific forests of silver fir and beech were assessed by the means of an online questionnaire. Respondents' level of agreement on 18 different statements about provisioning, cultural, regulating and supporting ecosystem services were evaluated in a 5-point Likert Scale. The next step was to find out what important variables were having a significant effect on the respondents' perceptions about ecosystem services in mixed versus monospecific forests. The variables belonged to the social profiles of the respondents including age, gender, profession, education level, among others. This was done by the means of stepwise regression models. The findings are discussed subsequently in the following three sections.

4.1 Respondents' perceptions on ecosystem services provided by mixed forests compared to monospecific forests of fir and beech trees

We found most respondents perceived that mixed forests provide better/preferred regulating, cultural and supporting ecosystem services than monospecific forests of fir and beech. Supporting services received most positive perceptions, while provisioning services were perceived to be equally provided in mixed and monospecific stands or even better in monospecific stands. These results are consistent with the results from peer-reviewed literature, as it was assumed that mixed forests ensure higher ecosystem functionality and show higher stability, resistance and resilience against extreme events, such as drought and storms [12,41]. In addition, higher diversity of tree species is promoted in forests as an adaptive measure to climate change impacts. A major discrepancy was found between respondents' perceptions and literature results on biomass productivity. While peer-reviewed literature indicate higher productivity in mixed species stands [42], respondents perceived productivity to be rather equal or worse in mixed compared to monospecific stands. A series of studies have exposed that higher biodiversity in forests promotes the functionality of ecosystems, such as primary production, decomposition, nutrient cycling and trophic interaction; thus, ensuring a better provision of ecosystem services, including food production, climate regulation, enhanced vitality, among others [7,19,20,43-45]. As a result, there is a growing trend for increasing the cover of mixed forests as a climate change adaptation strategy in Germany [46]. However, although there is a general support for mixed forests by the public and scientific community, private forest owners and some forest economists still perceive that mixed forests are less profitable than monospecific stands of fast growing tree species. There have been many studies on the ecological benefits of mixed forests, especially in the context of climate change, yet sound economic assessments of mixed forests are still rare [47]. For instance, from a risk-aversion perspective, the economic value of mixed forests is believed to be greater, as a higher number of species is translated into higher resistance towards extreme events. In the case of beech and fir, admixture of beech to monospecific fir stands is believed to increase stability and resilience [11]. Furthermore, it is known that mixed forests could deal better with the uncertainties of the future climate development than monospecific forests [48]. Nonetheless, 

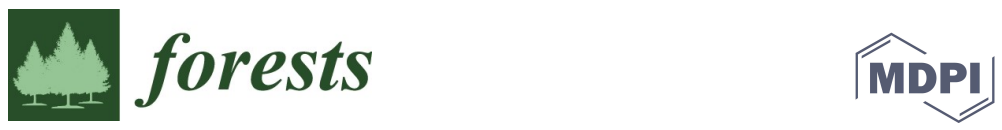

this risk-aversion value is not always integrated in forestry financial models; as such the economic benefits are not visible. As a result, many foresters might not yet be convinced of mixed forests being economically more profitable. In addition, many of them might be unconvinced about adopting modern approaches of forest management and bio-economic modelling to value mixed forests. This might explain the neutral to negative respondents' perceptions on provisioning ecosystem services in mixed forests. It is noteworthy to mention that supporting services, which obtained most of the positive levels of agreement, were also the ones obtaining the least D.K. ("I don't know") answers. On the other hand, provisioning services, which got the most neutral to negative responses, were the ones obtaining most D.K. answers. Our findings corroborate Carnol et al.'s [9] study who obtained similar results in Belgium. In their study, supporting, regulating and cultural ecosystem services were likewise perceived to be better in mixed species stands, while provisioning ecosystem services were perceived to be equal in mixed and monospecific stands.

Timber yield, profitability, hunting potential and biomass productivity (all provisioning ecosystem services) are specific topics that require a certain degree of technical knowledge, in order to be able to build an opinion on. Hence, people who do not study forestry, nor have a forestry related job, are less likely to be able to build their own opinion based on knowledge and/or experience. Conversely, cultural ecosystem services, such as tourism attractiveness and aesthetic value are easier to be understood by people, regardless of their professional or academic background. There is no specific knowledge needed to build an opinion on many of the cultural services, as perceptions on these services can be based on people's own experiences and aesthetic preferences. Furthermore, people are directly dependent on cultural ecosystem services in their every-day life, such as recreational activities and tourism among many others [15]. Supporting ecosystem services, such as resistance to drought, diseases and storms, together with resilience to climate change impacts, are topics that are addressed continuously in the policy agenda and in the media, as they play a crucial role in the climate change debate [49,50]. Furthermore, extreme events such as storms, floods and droughts are already happening in different parts of the world; as a result, climate change issues are being broadcasted more in mainstream German media [51-53]. Therefore, people might be more aware of the importance of supporting ecosystem services for climate change adaptation and mitigation, as well as for security and human well-being.

4.2 Respondents' preferences between mixed and monospecific forests of fir and beech

Besides perceived ecosystem services, another important variable in the present study was the respondents' preferences between mixed and monospecific forests of silver fir and beech. The aim was to find out first, whether the people surveyed preferred mixed over monospecific forests and second, to test if those preferences influenced respondents' perceptions on ecosystem services.

The question of having a pleasant feeling was a subjective question, which aims to get an opinion of the respondent based both on his/her emotional and rational processes of thinking of mind [54].

Whether a person gets a pleasant feeling from a certain forest landscape, not only depends on visual values, such as scenic beauty and preferred forest features, which are based on emotions, but also on 


\section{forests}

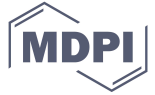

education, and practical or theoretical knowledge based on available information. For instance, preferences might have been based on information about ecological advantages of mixed compared to monospecific forests in the context of climate change. This would account for more of a rational thought process. Two past studies on public preferences for different forest types revealed that mixed forests are generally preferred over monospecific forests by people $[55,56]$; which corroborates our results.

The response to the question about feeling "at home" (sense of home or in German "Heimatgefühl") in a certain forest type was intriguing. The initial motivation of asking this question was to test whether people would feel more "at home" in coniferous forests, rather than mixed forests; as they might associate forests in the hilly region of southwest Germany with monospecific forests of two main conifer species: silver fir and Norway spruce. Accordingly, it was expected that they would feel more at home in a silver fir forest rather than in a mixed fir-beech forest. Contrary to our expectations, it was found that most of the respondents felt more "at home" in mixed beech-fir forests. An explanation for this result might be that most of the survey respondents were holders of university or technical degree and second, the majority of them were young persons aged between 18 to 40 years. Thus, they might be more aware/informed of the potential natural vegetation in southwest Germany, which would be mostly beech dominated mixed forests with silver fir and other species.

4.3 Influence of multiple factors on respondents' perceptions

Overall, respondents' perceptions on all four types of ecosystem services were influenced by their feeling that mixed forests harbour higher number of old and big trees. Edwards et al. [55] had done a survey using the Delphi technique in Great Britain, Nordic Region, Central Europe and Iberian Peninsula and found that "size of trees within stand" was the most important variable influencing peoples' preferences for the potential forest types. Gundersen and Frivold [54] had reviewed 53 studies (published from 1972 to 2004) on forest landscape preferences in Fennoscandia. They found people prefer forests with an irregular structure constituted of smaller as well as big trees, due to their provision of higher recreation values in contrast to regular even aged forests. In addition, Ribe [56] listed 14 studies (published from 1967 to 1986) which showed tree size was an important factor for people's preferences to visit urban parks, national parks and other recreational forests. Old and big trees sustain wider range of ecosystem functions and services, such as carbon storage, soil development, water storage, wood volume, and provision of habitat; thus, allowing for the occurrence of higher species diversity. For instance, arboreal wildlife species prefer large trees as habitat and several wood-living species are restricted to large dimensions. Likewise, many threatened species among the insects and fungi only develop in large trees [57]. Hence, maintaining some old trees in forest stands can be a crucial strategy for maintaining biodiversity during impacts caused by climate change [58]. This may explain the link between respondents' perceptions on the abundance of old trees in mixed forests and the provision of preferred ecosystem services. Respondents who perceive that old trees are usually more likely to be found in mixed forests and at the same time, are aware of the ecological advantages of maintaining old growth in forests, will consequently perceive 


\section{forests}

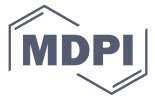

that mixed forests provide better ecosystem services than monospecific forests. People`s perception on the occurrence of big trees may also be related to the silvicultural systems associated with management of mixed and monospecific forest stands. Monospecific forests are generally managed by a clear-felling system, which requires the creation of big gaps to promote natural regeneration and systematic removal of big trees after certain diameter has been reached. In contrast, mixed forests stands were generally managed under the principles of close to nature silviculture or Dauerwald systems, where certain proportion of big trees are kept aside as habitat trees [59].

Respondents, who experienced a greater feeling of pleasantness in mixed forests, were more likely to perceive that supporting, regulating and cultural ecosystem services are better provided in mixed forests. The positive relationships between perceptions on cultural services and pleasantness of mixed forests can be explained by the fact that public preferences of natural landscapes (in this case, forest landscapes), are usually based on perceptions of "aesthetic beauty" [55,56]. Brown and Daniel [60] reported visual attractiveness increases pleasantness of forests to visitors and influences the recreational value of a forest. Nevertheless, these perceptions can vary depending on the social profiles of respondents. Traditionally, scenic beauty was considered a by-product of well-managed park-like forests near to human habitation in Europe. However, public concerns on aesthetic beauty in natural environments or wilderness areas started to gain more importance; thus, innovative techniques to measure "aesthetic value of natural landscapes" started to emerge. Since 1970, there have been many empirical assessments about public preferences of natural landscapes scenery, particularly of forests [56]. In addition, according to Ribe [56], scenic beauty was not only considered an important "forest product", but also perceptions of beauty of forests were important measures for forest management-decision making. Yarrow [61] for instance, found that many British respondents were willing to compromise timber yield values to a certain degree to increase beauty of the forests. When assessing public preferences between managed and unmanaged forests among French respondents, he found that choice was influenced by social groups, age and profession. For example, he reported that young men, people living in rural areas, industrial workers and farmers preferred managed forests, while young women and more educated Parisians preferred unmanaged forests. In our study as well, we found that male respondents were less likely to believe that mixed forests provide better cultural services than monospecific forests. Similarly, Martín-López et al. [17] also found a different environmental awareness between male and female, stating that females were more likely to perceive the capacity of an ecosystem to provide ecosystem services. In particular, female respondents were more likely of perceiving regulating services, while male respondents were more likely of perceiving provisioning services. In addition, Carnol et al. [9]found, that socio-economic context, together with a rural versus a highly urbanized residential place; can explain differences in stakeholders' perceptions. The finding that perceptions on regulating and supporting services were positively related to higher pleasantness of mixed forests suggests that choice of respondents was not only based on preferences of "visual beauty", but also on information and previous local or scientific knowledge. More precisely, respondents might have been informed about the ecological advantages of mixed forests in the context of climate change, as discussion on this topic is growing and has been becoming an agenda of green politics. Carnol et al. [9] found similarly, that local or scientific 


\section{forests}

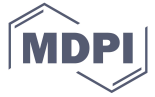

knowledge has an influence on stakeholders' perceptions on the provision of ecosystem services in mixed forests.

Surprisingly, a higher "home-feeling" in mixed forests had an influence on respondents' perception of a better provision of not only cultural, but also provisioning services in mixed forests. This interesting finding reinforces our explanation that most of respondents are aware of the natural potential vegetation in Southwest Germany and are informed of the multiple advantages of mixed forests over monospecific forests.

Similarly to the findings by Yarrow [61], Plieninger et al. [16], Martín-López [17] and Carnol et al. [9], we found that socio demographic profiles, in our study particularly age and education level, are also important explanatory variables influencing respondents' perceptions on ecosystem services. As such, respondents between 18 and 25 years old were more likely to perceive a higher provision of supporting ecosystem services in mixed forest, suggesting a possible higher awareness of younger respondents about the higher resilience of mixed forests in the context of climate change. In contrast to the findings by Martín-López et al. [17], which have shown that people with higher formal education level are more likely to perceive a better provision of ecosystem services in mixed forests, our results show that students and people with technical degrees were more likely to perceive better supporting, regulating and cultural services in mixed forests, compared to people holding a university degree. However, it is worth mentioning that unlike Martín-López et al. [17], all our respondents had obtained a certain level of formal education. This result suggests that a higher formal education is not necessarily associated to the perception of a better provision of ecosystem services in mixed forests. In section 4.1 we suggest that the negative perceptions on provisioning ecosystem services in mixed forests might come mostly from respondents employed in the forestry sector. However, the regression analyses showed significant results only for cultural services, as this stakeholder group was less likely to perceive a higher provision of cultural services in mixed forests. More research about the perceptions people employed in the forestry sector, including personal interviews, is needed in order to be able to draw conclusions on this finding.

\section{Conclusions}

In the present study, perceived ecosystem services provided by mixed compared to monospecific forests of silver fir and European beech forests were assessed by the means of an online questionnaire. The findings stated that overall there is a general awareness of mixed forests providing better ecosystem services than monospecific forests of fir and beech. In addition, mixed forests are generally preferred over monospecific forests. It was also found out that supporting, regulating and cultural services were perceived to be better in mixed rather than monospecific forests, while provisioning services were perceived as being equal or better provided in monospecific forests of fir and beech. The contrasting perceptions on provisioning services highlighted the need for better communication and information flow on profitability, biomass and timber productivity in mixed forests. Lastly, the study demonstrated that social profiles and preferences have a significant influence in perceived ecosystem services. It was found that respondents, who perceived higher abundance of old and big 


\section{forests}

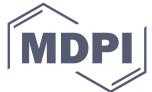

trees in mixed forests were more likely to fully agree on a higher provision of ecosystem services in mixed forests. The same effect was caused by feeling more pleasant in mixed forests. One of the major contributions of this study is that this has been the first study in Germany assessing people's perceptions on ecosystem services in mixed and monospecific forests of fir and beech. Additionally, this study assessed cultural ecosystem services, which have been rarely assessed in literature, except for economic assessments of tourism and recreation. Finally, it contributed to fill the gap between formal scientific knowledge and people's perceptions on the provision of forest ecosystem services. Conclusively, the study shows the paramount importance of further research on this field, as it provides an understanding of people's perceptions and motivations with regards to their environment. These perceptions, if better understood by policy makers, will lead to effective and efficient policies of forest management being implemented, which will in turn provide more viable ways to mitigate and adapt to climate change in the long run.

This study contribute to the achievement of the Sustainable Development Goals 13 "Climate Action" and 15 "Life on Land", as it analyses public attitudes and perceptions on mixed forests and enhances the public awareness about the importance of ecosystem services provided by them. Furthermore, it improves the knowledge about the resilience and adaptive capacity of forests in Southwest Germany towards negative impacts caused by climate change. In addition, it serves as an instrument to contribute to Goal 15.9, which aims to integrate ecosystem and biodiversity values into national and local planning [8]. 


\section{forests}

Author Contributions: CR and SS conceptualized the study. IY, CR, and SS develop the questionnaire. IY did the online survey. IY and SS analyzed the data. IY, CR, and SS wrote the paper. CR and SS provided pedagogic supervision to IY.

Funding: This research was funded by the Forest Climate Fund, German Federal Ministry for Food and Agriculture (Waldklimafond, Bundesministerium für Ernährung und Landwirtschaft). The grant number was FE.5160.0027.4143. The APC was funded by the Open Access Fund of Karlsruhe Institute of Technology.

Conflicts of Interest: The authors declare no conflict of interest. The funders had no role in the design of the study; in the collection, analyses, or interpretation of data; in the writing of the manuscript, and in the decision to publish the results.

\section{References}

1. MEA. Millennium ecosystem assessment. Ecosystems and human wellbeing: a framework for assessment Washington, DC: Island Press 2005.

2. Edenhofer, O.; Pichs-Madruga, R.; Sokona, Y.; Farahani, E.; Kadner, S.; Seyboth, K.; Adler, A.; Baum, I.; Brunner, S.; Eickemeier, P. Ipcc, 2014: Summary for policymakers. Climate change 2014.

3. Schaich, H.; Milad, M. Forest biodiversity in a changing climate: Which logic for conservation strategies? Biodiversity and Conservation 2013, 22, 1107-1114.

4. Milad, M.; Schaich, H.; Konold, W. How is adaptation to climate change reflected in current practice of forest management and conservation? A case study from germany. Biodiversity and Conservation 2013, 22, 1181-1202.

5. Alley, R.B.; Marotzke, J.; Nordhaus, W.D.; Overpeck, J.T.; Peteet, D.M.; Pielke, R.A.; Pierrehumbert, R.T.; Rhines, P.B.; Stocker, T.F.; Talley, L.D. Abrupt climate change. Science 2003, 299, 2005-2010.

6. Spiecker, H. Silvicultural management in maintaining biodiversity and resistance of forests in europe - temperate zone. Journal of Environmental Management 2003, 67, 55-65.

7. Gamfeldt, L.; Snäll, T.; Bagchi, R.; Jonsson, M.; Gustafsson, L.; Kjellander, P.; Ruiz-Jaen, M.C.; Fröberg, M.; Stendahl, J.; Philipson, C.D. Higher levels of multiple ecosystem services are found in forests with more tree species. Nature Communications 2013, 4, 1340.

8. UN. Sustainable development goals: 17 goals to transform our world. https://www.un.org/sustainabledevelopment/sustainable-development-goals/ (25.06.2018),

9. Carnol, M.; Baeten, L.; Branquart, E.; Grégoire, J.-C.; Heughebaert, A.; Muys, B.; Ponette, Q.; Verheyen, K. Ecosystem services of mixed species forest stands and monocultures: Comparing practitioners' and scientists' perceptions with formal scientific knowledge. Forestry: An International Journal of Forest Research 2014, 87, 639-653.

10. Nadrowski, K.; Wirth, C.; Scherer-Lorenzen, M. Is forest diversity driving ecosystem function and service? Current Opinion in Environmental Sustainability 2010, 2, 75-79. 
Forests 2018, 9, x FOR PEER REVIEW

11. Kölling, C.; Zimmermann, L. Die anfälligkeit der wälder deutschlands gegenüber dem klimawandel. Gefahrstoffe-Reinhaltung der Luft 2007, 67, 259-268.

12. Bodin, P.; Wiman, B.L. The usefulness of stability concepts in forest management when coping with increasing climate uncertainties. For. Ecol. Manage. 2007, 242, 541-552.

13. EU-Parliament. Our life insurance, our natural capital: An eu biodiversity strategy to 2020:European parliament resolution of 20 april 2012 on our life insurance, our natural capital: An eu biodiversity strategy to 2020 (2011/2307(ini))

http://ec.europa.eu/environment/nature/biodiversity/comm2006/pdf/EP_resolution_ april2012.pdf $(01 / 12 / 2017)$,

14. Chan, K.M.; Satterfield, T.; Goldstein, J. Rethinking ecosystem services to better address and navigate cultural values. Ecological economics 2012, 74, 8-18.

15. Guo, Z.; Zhang, L.; Li, Y. Increased dependence of humans on ecosystem services and biodiversity. PloS one 2010, 5, e13113.

16. Plieninger, T.; Dijks, S.; Oteros-Rozas, E.; Bieling, C. Assessing, mapping, and quantifying cultural ecosystem services at community level. Land use policy 2013, 33, 118-129.

17. Martín-López, B.; Gómez-Baggethun, E.; García-Llorente, M.; Montes, C. Tradeoffs across value-domains in ecosystem services assessment. Ecological Indicators 2014, 37, 220-228.

18. Geßler, A.; Keitel, C.; Kreuzwieser, J.; Matyssek, R.; Seiler, W.; Rennenberg, H. Potential risks for european beech (fagus sylvatica 1.) in a changing climate. Trees 2007, 21, 1-11.

19. Pretzsch, H.; Schütze, G.; Uhl, E. Resistance of european tree species to drought stress in mixed versus pure forests: Evidence of stress release by inter-specific facilitation. Plant Biology 2013a, 15, 483-495.

20. Chakraborty, T.; Saha, S.; Matzarakis, A.; Reif, A. Influence of multiple biotic and abiotic factors on the crown die-back of european beech trees at their drought limit. Flora 2017, 229, 58-70.

21. Magh, R.-K.; Grün, M.; Knothe, V.E.; Stubenazy, T.; Tejedor, J.; Dannenmann, M.; Rennenberg, H. Silver-fir (abies alba mill.) neighbors improve water relations of european beech (fagus sylvatica 1.), but do not affect n nutrition. Trees 2017, 1-12.

22. Huss, J. Mischwald zwischen wunsch und wirklichkeit. Forstwissenschaftliches Centralblatt 1987, 106, 114-132.

23. Spiecker, H.; Hansen, J.; Klimo, E.; Skovsgaard, J.P.; Sterba, H.; von Teuffel, K. Norway spruce conversion: Options and consequences. Brill Leiden: 2004; Vol. 18.

24. Baumgarten, M.; von Teuffel, K. Nachhaltige waldwirtschaft in deutschland. In Waldumbau, Springer: 2005; pp 1-10.

25. von-Teuffel, K.; Baumgarten, M.; Hanewinkel, M.; Konold, W.; Sauter, U.H.; Spiecker, H.; Wilpert, K. Waldumbau: Für eine zukunftsorientierte waldwirtschaft. Springer-Verlag: 2005.

26. Ellenberg, H.; Leuschner, C. Vegetation mitteleuropas mit den alpen: In ökologischer, dynamischer und historischer sicht. Utb: 2010; Vol. 8104. 
27. Moosmayer, H.-U. Langfristige regionale waldbauplanung in baden-württemberg: Grundlagen und ergebnisse. Selbstverlag der Landesforstverwaltung BadenWürttemberg: 2002.

28. Ammer, C.; Albrecht, L.; Borchert, H.; Brosinger, F.; Dittmar, C.; Elling, W.; Ewald, J.; Felbermeier, B.; Von Gilsa, H.; Huss, J. Future suitability of beech (fagus sylvatica 1.) in central europe: Critical remarks concerning a paper of rennenberg et al.(2004). Allgemeine Forst und Jagdzeitung 2005, 176, 60-67.

29. Kändler, G.; Cullmann, D.; Versuchs, F. Der wald in baden-württemberg. Ausgewählte Ergebnisse der dritten Bundeswaldinventur. Forstliche Versuchsund Forschungsanstalt Baden-Württemberg, Freiburg 2014.

30. Polley, H.; Hennig, P.; Kroiher, F.; Marks, A.; Riedel, T.; Schmidt, U.; Schwitzgebel, F.; Stauber, T. Der wald in deutschland: Ausgewählte ergebnisse der dritten bundeswaldinventur. Berlin: 2014.

31. EUFORGEN. Species distribution: European forest genetic resources programme. http://www.euforgen.org/species/ (01/12/2017),

32. enuvo-GmBH. Umfrageonline. https://www.umfrageonline.com (17.09.2017),

33. Valentine, G. Tell me about...: Using interviews as a research methodology. Methods in human geography: A guide for students doing a research project 1997, 110-126.

34. Likert, R. A technique for the measurement of attitudes. Archives of psychology 1932.

35. Krosnick, J.A.; Presser, S. Question and questionnaire design. Handbook of Survey Research 2010, 2, 263-314.

36. Thompson, I.; Mackey, B.; McNulty, S.; Mosseler, A. In Forest resilience, biodiversity, and climate change, A synthesis of the biodiversity/resilience/stability relationship in forest ecosystems. Secretariat of the Convention on Biological Diversity, Montreal. Technical Series, 2009; p 67.

37. Yang, H. The case for being automatic: Introducing the automatic linear modeling (linear) procedure in spss statistics. Multiple Linear Regression Viewpoints 2013, 39, 27-37.

38. IBM. Autometic linear modeling. https://www.ibm.com/support/knowledgecenter/en/SSLVMB 20.0.0/com.ibm.spss. statistics.cs/linear_insurance howto.htm (27.11.2017),

39. R-Development-Core-Team $R$ statistical software, The R Foundation: Vienna, 2017.

40. Lemon, J. Plotrix: A package in the red light district of r. R-news 2006, 6, 8-12.

41. Milad, M.; Schaich, H.; Bürgi, M.; Konold, W. Climate change and nature conservation in central european forests: A review of consequences, concepts and challenges. For. Ecol. Manage. 2011, 261, 829-843.

42. Piotto, D. A meta-analysis comparing tree growth in monocultures and mixed plantations. For. Ecol. Manage. 2008, 255, 781-786.

43. Forrester, D.I. Ecological and physiological processes in mixed versus monospecific stands. In Mixed-species forests, Springer: 2017; pp 73-115. 
44. Mori, A.S.; Lertzman, K.P.; Gustafsson, L. Biodiversity and ecosystem services in forest ecosystems: A research agenda for applied forest ecology. Journal of Applied Ecology 2017, 54, 12-27.

45. Pretzsch, H.; Bielak, K.; Block, J.; Bruchwald, A.; Dieler, J.; Ehrhart, H.-P.; Kohnle, U.; Nagel, J.; Spellmann, H.; Zasada, M. Productivity of mixed versus pure stands of oak (quercus petraea (matt.) liebl. And quercus robur 1.) and european beech (fagus sylvatica 1.) along an ecological gradient. European Journal of Forest Research 2013b, 132, 263-280.

46. Reif, A.; Brucker, U.; Kratzer, R.; Schmiedinger, A.; Bauhus, J. Waldbewirtschaftung in zeiten des klimawandels-synergien und konfliktpotenziale zwischen forstwirtschaft und naturschutz. Naturschutz und Landschaftsplanung 2010, 42, 261-266.

47. Knoke, T.; Ammer, C.; Stimm, B.; Mosandl, R. Admixing broadleaved to coniferous tree species: A review on yield, ecological stability and economics. European Journal of Forest Research 2008, 127, 89-101.

48. Bolte, A.; Ammer, C.; Löf, M.; Madsen, P.; Nabuurs, G.-J.; Schall, P.; Spathelf, P.; Rock, J. Adaptive forest management in central europe: Climate change impacts, strategies and integrative concept. Scandinavian Journal of Forest Research 2009, 24, 473-482.

49. Bundesregierung. Deutsche anpassungsstrategie an den klimawandel - vom bundeskabinett am 17. Dezember 2008 beschlossen

http://www.bmub.bund.de/fileadmin/bmuimport/files/pdfs/allgemein/application/pdf/das_gesamt bf.pdf (30/11/2017),

50. Umweltbundesamt. Effects of climate change clearly noticeable in germany: Joint press release of the federal environment agency and the federal ministry for the environment, nature conservation, building and nuclear safety. https://www.umweltbundesamt.de/en/press/pressinformation/effects-of-climatechange-clearly-noticeable-in (30/11/2017),

51. Bayerischer-Rundfunk. Extremwetter durch klimawandel: Mehr starkregen, dürren, hitzewellen und orkane. http://www.br.de/themen/wissen/wetterextremwetter-klimawandel-100.html (30/11/2017),

52. Süddeutsche-Zeitung. Trockenheit in deutschland: Die große dürre. http://www.sueddeutsche.de/wissen/trockenheit-in-europa-die-grosse-duerre1.2608455\#redirectedFromLandingpage (30/11/2017),

53. SWR-Fernsehen. Klimawandel - wie verändert sich der südwesten? . https://www.swr.de/betrifft/klimawandel-wie-veraendert-sich-der-suedwesten//id=98466/did=20403428/nid=98466/1e6tvnk/index.html (20/11/2017),

54. Gundersen, V.S.; Frivold, L.H. Public preferences for forest structures: A review of quantitative surveys from finland, norway and sweden. Urban Forestry \& Urban Greening 2008, 7, 241-258.

55. Edwards, D.; Jay, M.; Jensen, F.; Lucas, B.; Marzano, M.; Montagné, C.; Peace, A.; Weiss, G. Public preferences across europe for different forest stand types as sites for recreation. Ecology and Society 2012, 17. 
56. Ribe, R.G. The aesthetics of forestry: What has empirical preference research taught us? Environmental Management 1989, 13, 55-74.

57. Lutz, J.A.; Larson, A.J.; Swanson, M.E.; Freund, J.A. Ecological importance of large-diameter trees in a temperate mixed-conifer forest. PloS one 2012, 7, e36131.

58. Noss, R.F. Beyond kyoto: Forest management in a time of rapid climate change. Conservation Biology 2001, 15, 578-590.

59. Brang, P.; Spathelf, P.; Larsen, J.B.; Bauhus, J.; Boncčìna, A.; Chauvin, C.; Drössler, L.; García-Güemes, C.; Heiri, C.; Kerr, G. Suitability of close-to-nature silviculture for adapting temperate european forests to climate change. Forestry: An International Journal of Forest Research 2014, 87, 492-503.

60. Brown, T.C.; Daniel, T.C. Modeling forest scenic beauty: Concepts and application to ponderosa pine; US Department of Agriculture, Forest Service, Rocky Mountain Forest and Range Experiment Station: 1984.

61. Yarrow, C. A preliminary survey of the public's concepts of amenity in british forestry. Forestry 1966, 39, 59-67. 